\title{
Chikungunya Virus Infection-associated Arthralgia in Adult Jamaicans Post-outbreak
}

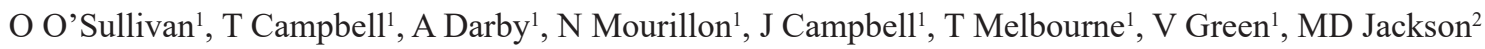

\begin{abstract}
Objective: To report demographic and self-reported clinical characteristics associated with persistent and severe arthralgia 8-12 months post-chikungunya virus (CHIKV) infection.

Methods: A cross-sectional study of 306 adults who self-reported CHIKV infection was conducted. Subjects were consecutively enrolled at public primary healthcare centres in urban and rural areas in Jamaica. Adults with arthralgic conditions were compared with those who reported no arthralgia. Binary logistic regression models were used to determine demographic and self-reported clinical factors associated with severe arthralgia and persistent arthralgia. Results: Most subjects (70.3\%) reported arthralgia after CHIKV outbreak (age: $47.6 \pm 18.5$ years). Medical consultation (36.2\%) and laboratory confirmation (1.4\%) were low. The prevalence of persistent and severe arthralgia in the previous month was $30.3 \%$ and $27.5 \%$, respectively. Severe arthralgia was associated with the female gender (odds ratio (OR): $2.44 ; 95 \%$ confidence level (CI): 1.08, 5.52) and pre-existing arthritis (OR: 3.78; 95\% CI: 1.23, 11.62). Females showed a greater likelihood of persistent arthralgia (OR: 2.18; 95\% CI: 1.09, 4.39).

Conclusion: Self-perceived arthralgia was an important feature 8-12 months post-CHIKV infection and has implications for the recognition and management of arthritis/rheumatic conditions.
\end{abstract}

Keywords: Arthralgia, chikungunya virus infection, Jamaica

\section{Artralgia asociada con la infección del virus de Chikunguña en jamaicanos adultos con posterioridad al brote}

O O’Sullivan ${ }^{1}$, T Campbell ${ }^{1}$, A Darby ${ }^{1}$, N Mourillon ${ }^{1}$, J Campbell ${ }^{1}$, T Melbourne ${ }^{1}$, V Green ${ }^{1}$, MD Jackson ${ }^{2}$

\section{RESUMEN}

Objetivo: Reportar las características clínicas demográficas y auto-reportadas asociadas con una artralgia persistente y severa de 8-12 meses tras la infección del virus de chikunguña $(\mathrm{CHIKV})$.

Métodos: Se llevó a cabo un estudio transversal de 306 adultos que auto-reportaron su infección de CHIKV. Los sujetos fueron alistados consecutivamente en centros públicos de atención primaria en zonas urbanas y rurales de Jamaica. Los adultos con condiciones artrálgicas fueron comparados con adultos que no reportaron artralgia alguna. Los modelos de regresión

From: ${ }^{1}$ Medical student, Department of Community Health and Psychiatry, Faculty of Medical Sciences, The University of the West Indies, Mona, Kingston, Jamaica, West Indies and ${ }^{2}$ Department of Community Health and Psychiatry, The University of the West Indies, Mona, Kingston, Jamaica, West Indies.
Correspondence: Professor MD Jackson, Department of Community Health and Psychiatry, The University of the West Indies, Mona, Kingston 7, Jamaica, West Indies. Email: maria.jackson@uwimona. edu.jm 
logística binaria fueron utilizados para determinar los factores clínicos demográficos y autoreportados que se asocian con artralgia severa y artralgia persistente.

Resultados: La mayoría de los sujetos (70.3\%) reportaron artralgia después del brote de CHIKV (edad: $47.6 \pm 18.5$ años). La consulta médica (36.2\%) y la confirmación del laboratorio (1.4\%) fueron bajas. La prevalencia de la artralgia persistente y la severa en el mes anterior fue de $30.3 \%$ y $27.5 \%$, respectivamente. La artralgia severa estuvo asociada al género femenino (odds-ratio (OR): 2.44; intervalo de confianza (IC): 1.08, 5.52), y artritis preexistente (OR: 3.78; 95\% (IC: 1.23, 11.62). Las hembras mostraron una mayor probabilidad de artralgia persistente (OR: 2.18; 95\% IC: 1.09, 4.39).

Conclusión: La artralgia auto-percibida fue una característica importante de la infección post-CHIKV de 8-12 meses, y tiene implicaciones para el reconocimiento y tratamiento de la artritis y las condiciones reumáticas.

Palabras clave: Artralgia, infección por virus de chikunguña, Jamaica

West Indian Med J 2018; 67 (3): 191

\section{INTRODUCTION}

The chikungunya virus (CHIKV) infection is caused by a single-stranded ribonucleic acid virus belonging to the Alphavirus genus of the Togaviridae family and is transmitted primarily through the female Aedes aegypti and Aedes albopictus mosquito (1). Outbreaks of the CHIKV have been reported in Africa, Asia, Europe, India and the Pacific Islands (1-3) and first emerged in the Caribbean region (St Martin) in 2013 (4). The CHIKV has subsequently spread to other Caribbean islands (5), including Jamaica.

In humans, muscle satellite cells (6), epithelial and endothelial cells, fibroblasts, dendritic cells, B cells and macrophages become susceptible to the infection (7). During the acute phase, clinical manifestations of the infection have a relatively short incubation period (1-12 days), and acute arthritis results from damaged collagen and altered connective tissue metabolism in cartilage and joints (8). Symptomology is usually shortlived, and most patients recover fully. Nevertheless, a sub-group of patients experience persistent arthralgia for extended periods. Chikungunya-induced arthralgia is often bilateral and symmetric and largely affects distal joints, frequently accompanied by swelling (9). A recent systematic review and meta-analysis of chronic inflammatory arthritis associated with post-CHIKV infection showed that $40 \%$ of patients were likely to develop chronic inflammatory rheumatism. Studies of long-term sequelae (follow-up period: $\geq 18$ months) suggested that $32 \%$ of cases were likely to show evidence of chronic arthritis (10).
Jamaica, a CHIKV-naïve population, had an epidemic from July 2014 to March 2015. The Pan American Health Organization and World Health Organization reported that CHIKV infection was highest in 2014 (total incidence rate: 54 cases per 100000 population) and decreased to 11 cases per 100000 population in 2015 (11). In 2016, the total incidence rate of CHIKV infection was 7 cases per 100000 (11). The National Surveillance Unit of the Ministry of Health in Jamaica documented 14 notifications of CHIKV-related deaths.

The characteristics and consequences of CHIKV infection in Caribbean populations have been described (5, 12-14). However, only two English-speaking Caribbean countries [US Virgin Islands (USVI) and Jamaica] have published reports of the infection (1517). Duncan et al highlighted the clinical presentation of CHIKV illness during the acute phase of the disease in Jamaica (17). An investigation by Feldstein et al of the long-term outcomes of the disease in the USVI showed a 2.5- and 2.9-fold increased risk for persistent arthralgia at 6 and 12 months, respectively, after the acute phase (16).

In this report, we present self-reported prevalence of persistent arthralgia as well as quality of the pain (severe arthralgia) 8-12 months post-acute infection in Jamaica and further identify demographic and clinical factors associated with these outcomes.

\section{SUBJECTS AND METHODS}

The study was conducted between July 6 and 17, 2015. All subjects were assured of anonymity and 
confidentiality, and information was treated in a confidential manner. Informed consent was obtained from all participants included in the study.

The study was conducted in accordance with The World Medical Association's Declaration of Helsinki - Ethical Principles for Medical Research Involving Human Subjects (18).

\section{Study design and sample}

This cross-sectional designed study enrolled adult males and females who were attending urban and rural public primary health care centres who reported (self-perceived and practitioner-confirmed) CHIKV infection between 2014 and 2015. Equal proportions of eligible men and women who were attending public health centres were recruited for the study. The response rate (number enrolled / number eligible) was $98.1 \%$.

\section{Eligibility criteria}

Subjects 18 years or older who met the case definition of CHIKV infection (ie fever, new onset of joint pains, rash and/or a confirmatory positive antibody testing for the virus) of the Ministry of Health, Jamaica, were recruited for the study. To determine CHIKV-associated arthralgia, patients were asked if they had joint pain (joint stiffness and swollen joints) subsequent to the infection and during the past four weeks.

\section{Exclusion criteria}

Pregnant women and children were excluded from the study.

\section{Data collection}

Information collected included demographic and socioeconomic factors, underlying co-morbidities (such as pre-existing arthritis, diabetes, hypertension and sickle cell disease), and duration and complications of CHIKV infection (including skin problems and joint pains). Patients who reported arthralgia were asked to characterize (persistent or intermittent) and describe the intensity of the pain (mild, moderate, severe or very severe). Information was obtained on CHIKV-associated health-seeking behaviour and confirmation of the infection. Data were obtained by an interviewer-administered questionnaire.

To determine the prevalence of CHIKV-associated persistent arthralgia, the proportion of patients who reported persistent arthralgia was compared with the proportion of those who reported no arthralgia. A similar approach was used to evaluate severe arthralgia (severe arthralgia versus no arthralgia).

\section{Statistical analyses}

Sociodemographic and clinical characteristics were compared according to arthralgia and non-arthralgia status using Chi-square statistics and the t-test as appropriate. Relationships between sociodemographic and clinical factors were initially screened by Spearman's correlation coefficient to determine their association with persistent arthralgia and severe arthralgia. Significantly correlated variables were subsequently included in regression models.

Binary logistic regression analyses were used to examine the effect of sociodemographic and clinical variables on the likelihood of persistent arthralgia and severe arthralgia. Patients who had reported persistent arthralgia and those who had reported severe arthralgia were compared with those with no arthralgia.

Statistical analyses were performed using the Statistical Package for Social Sciences version 21.0. Statistical significance was achieved when $p$ was $<0.05$.

\section{RESULTS}

\section{Characteristics of subjects}

The sample consisted of 306 subjects (153 males and 153 females) who self-reported CHIKV infection. Substantially more patients reported arthralgia (70.3\%; $215 / 306)$ than those who reported no arthralgia 8-12 months after acute illness (Table 1). Both genders were on average under 50 years old; however, more females than males reported arthralgia. There was no statistically significant difference between the proportions of arthralgic and non-arthralgic subjects who had comorbid conditions such as hypertension, diabetes and pre-existing arthritis.

Medical consultations were low (36.2\%), and 1.4\% of the arthralgic patients had laboratory confirmation of the infection (Table 1). Somewhat more females (45.4\%) than males (37.4\%) sought healthcare (data not shown). Most arthralgic subjects reported intermittent arthralgia $(70.2 \%)$, and acute symptoms tended to last from a few days to two weeks.

Table 2 describes the characteristics of arthralgic subjects who reported pain during the previous month. It shows that $74.4 \%(160 / 215)$ of the arthralgic patients had pain during the previous month. Most had mild to moderate joint pain, and the severity of pain did not differ by demographic factors. Subjects who reported 
Table 1: Demographic and self-reported clinical characteristics of Chikungunya arthralgic subjects and non-arthralgic subjects

\begin{tabular}{|c|c|c|}
\hline Characteristics & $\begin{array}{c}\text { Arthralgic } \\
\text { participants } \\
(\mathrm{n}=215) \\
\end{array}$ & $\begin{array}{c}\text { Non-arthralgic } \\
\text { participants } \\
(\mathrm{n}=91)\end{array}$ \\
\hline \multicolumn{3}{|l|}{ Gender: \%* } \\
\hline Males & $45.1(97)$ & $61.5(56)$ \\
\hline Females & $54.9(118)$ & $38.5(35)$ \\
\hline $\begin{array}{l}\text { Age (years): mean } \pm \text { standard } \\
\text { deviation (median) }\end{array}$ & $47.6 \pm 18.5(48.0)$ & $43.9 \pm 18.6(44.0)$ \\
\hline \multicolumn{3}{|l|}{ Education: $\% * *$} \\
\hline Primary & $34.6(74)$ & $32.2(29)$ \\
\hline Secondary & $50.9(109)$ & $54.4(49)$ \\
\hline Tertiary & $14.5(31)$ & $13.3(12)$ \\
\hline \multicolumn{3}{|l|}{ Area of residence: $\%$} \\
\hline Urban & $43.3(93)$ & $31.9(29)$ \\
\hline Rural & $56.7(122)$ & $68.1(62)$ \\
\hline \multicolumn{3}{|l|}{ Occupation***: } \\
\hline Unskilled & $21.6(45)$ & $22.2(20)$ \\
\hline Semi-skilled & $16.3(34)$ & $17.8(16)$ \\
\hline Skilled & $44.2(92)$ & $37.8(34)$ \\
\hline Technical/Professional & $12.5(26)$ & $10.2(9)$ \\
\hline Student & $5.3(11)$ & $12.2(11)$ \\
\hline \multicolumn{3}{|l|}{ Co-morbidity: \% } \\
\hline Hypertension & $35.8(77)$ & $27.5(25)$ \\
\hline Diabetes & $17.8(38)$ & $14.3(13)$ \\
\hline Pre-existing arthritis & $10.7(23)$ & $7.7(7)$ \\
\hline Asthma & $4.6(10)$ & $9.9(9)$ \\
\hline No pre-existing disease & $46.5(100)$ & $51.6(47)$ \\
\hline \multicolumn{3}{|l|}{ Healthcare-seeking behaviour: \% } \\
\hline Medical consultation & $36.2(78)$ & - \\
\hline Laboratory confirmation & $1.4(3)$ & - \\
\hline Self-diagnosis & $62.4(134)$ & - \\
\hline \multicolumn{3}{|l|}{ Arthralgia } \\
\hline Persistent & $30.7(66)$ & - \\
\hline Intermittent & $69.3(149)$ & - \\
\hline \multicolumn{3}{|l|}{ Duration of acute symptoms: \% } \\
\hline$<1$ week & $42.3(91)$ & - \\
\hline 1-2 weeks & $34.4(74)$ & - \\
\hline$\geq 3$ weeks & $23.3(50)$ & - \\
\hline
\end{tabular}

$* p<0.05$

** Data missing for two subjects.

*** Data missing for eight subjects: seven arthralgic and one non-arthralgic.

pre-existing arthritis (29.5\%) and hypertension (50.0\%) were more likely to experience severe arthralgia.

Most arthralgic subjects characterized arthralgia as being intermittent $(69.7 \%)$, and fewer reported persistent arthralgia (30.3\%) (Table 3). The frequency of occurrence did not vary by demographic variables or the presence of comorbid conditions.

Variables that were significantly correlated in univariate analyses were used in binary logistic regression analyses to identify significant associations of severe
Table 2: Characteristics of subjects reporting mild to severe arthralgia during the previous month $(\mathrm{n}=160)$

\begin{tabular}{|c|c|c|c|}
\hline & \multicolumn{3}{|c|}{ Severity of arthralgia } \\
\hline & Mild & Moderate & Severe \\
\hline Pain characteristics & $40.6(65)$ & $31.9(51)$ & $27.5(44)$ \\
\hline \multicolumn{4}{|l|}{ Gender: \% } \\
\hline Males & $53.8(35)$ & $41.2(21)$ & $34.1(15)$ \\
\hline Females & $46.2(30)$ & $58.8(30)$ & $65.9(29)$ \\
\hline \multicolumn{4}{|l|}{ Age (years): \% } \\
\hline$<25$ & $12.3(8)$ & $3.9(2)$ & $6.8(3)$ \\
\hline $25-40$ & $23.1(15)$ & $21.6(11)$ & $29.5(13)$ \\
\hline $41-59$ & $33.8(22)$ & $23.5(12)$ & $29.5(13)$ \\
\hline 60 or older & $30.8(20)$ & $51.0(26)$ & $34.1(15)$ \\
\hline \multicolumn{4}{|l|}{ Education: \%* } \\
\hline Primary & $23.4(15)$ & $47.1(24)$ & $47.7(21)$ \\
\hline Secondary & $59.4(38)$ & $41.2(21)$ & $50.0(22)$ \\
\hline Tertiary & $17.2(11)$ & $11.8(6)$ & $2.3(1)$ \\
\hline \multicolumn{4}{|l|}{ Area of residence: $\%$} \\
\hline Urban & $49.2(32)$ & $31.4(16)$ & $31.8(14)$ \\
\hline Rural & $50.8(33)$ & $68.6(35)$ & $68.2(30)$ \\
\hline \multicolumn{4}{|l|}{ Employment: \% } \\
\hline Employed & $69.2(45)$ & $74.5(38)$ & $63.6(28)$ \\
\hline Unemployed & $30.8(20)$ & $25.5(13)$ & $36.4(16)$ \\
\hline \multicolumn{4}{|l|}{ Pre-existing conditions: $\%$} \\
\hline Pre-existing arthritis** & $3.1(2)$ & $11.8(6)$ & $29.5(13)$ \\
\hline Diabetes & $18.5(12)$ & $21.6(11)$ & $29.5(13)$ \\
\hline Hypertension $* * *$ & $32.3(21)$ & $52.9(27)$ & $50.0(22)$ \\
\hline \multicolumn{4}{|l|}{ Healthcare-seeking behaviour: } \\
\hline Medical consultation*** & $39.1(25)$ & $45.1(23)$ & $63.6(28)$ \\
\hline
\end{tabular}

* Data missing for one subject.

$* * p<0.0001$

$* * * p<0.05$

arthralgia as well as persistent arthralgia post-CHIKV outbreak. Odds ratios (ORs) were calculated to estimate the strength of the relation of sociodemographic factors and the presence of comorbid conditions with severe or persistent arthralgia during the previous month.

Table 4 shows the likelihood of severe and persistent arthralgia by demographic and clinical factors. Compared to males, females were more likely to report severe (OR: 2.44; 95\% confidence level (CI): 1.08, 5.52) and persistent (OR: 2.18; 95\% CI: 1.09, 4.39) arthralgia. Subjects with pre-existing arthritis (OR: 3.78; 95\% CI: $1.23,11.62)$ showed increased odds for severe arthralgia.

\section{DISCUSSION}

In this investigation, we report arthralgia and the factors associated with persistent arthralgia as well as the quality of the pain (severe arthralgia) 8-12 months post-acute CHIKV infection. Just over half of the patients (52.3\%; $160 / 306$ ) reported arthralgia during the previous month. 
Table 3: Intermittent and persistent arthralgia by demographic factors and self-reported co-morbidities

\begin{tabular}{|c|c|c|}
\hline \multicolumn{3}{|c|}{$\begin{array}{ll} & \text { Arthralgia }\end{array}$} \\
\hline & $\begin{array}{c}\text { Intermittent } \\
\%(n)\end{array}$ & $\begin{array}{l}\text { Persistent } \\
\% \text { (n) }\end{array}$ \\
\hline Prevalence & $69.3(149)$ & $30.7(66)$ \\
\hline \multicolumn{3}{|l|}{ Gender: } \\
\hline Males & $47.0(70)$ & $42.2(28)$ \\
\hline Females & $53.0(79)$ & $57.6(38)$ \\
\hline \multicolumn{3}{|l|}{ Age (years): } \\
\hline$<25$ & $14.1(21)$ & $12.1(8)$ \\
\hline $25-40$ & $27.5(41)$ & $21.2(14)$ \\
\hline $41-59$ & $26.8(40)$ & $28.8(19)$ \\
\hline 60 or older & $31.5(47)$ & $37.9(25)$ \\
\hline \multicolumn{3}{|l|}{ Education*: } \\
\hline Primary & $34.9(52)$ & $30.8(20)$ \\
\hline Secondary & $49.7(74)$ & $58.5(38)$ \\
\hline Tertiary & $15.4(23)$ & $10.8(7)$ \\
\hline \multicolumn{3}{|l|}{ Area of residence: } \\
\hline Urban & $43.0(64)$ & $43.9(29)$ \\
\hline Rural & $57.0(85)$ & $56.1(37)$ \\
\hline \multicolumn{3}{|l|}{ Employment: } \\
\hline Employed & $69.1(103)$ & $62.1(41)$ \\
\hline Unemployed & $30.9(46)$ & $37.9(25)$ \\
\hline \multicolumn{3}{|l|}{ Pre-existing co-morbidities: } \\
\hline Pre-existing arthritis & $9.4(14)$ & $15.2(10)$ \\
\hline Diabetes & $16.8(25)$ & $21.2(14)$ \\
\hline Hypertension & $34.9(52)$ & $37.9(25)$ \\
\hline \multicolumn{3}{|c|}{ Healthcare-seeking behaviour: } \\
\hline Medical consultation & $38.9(58)$ & $50.0(33)$ \\
\hline
\end{tabular}

* Data missing for two subjects.

Table 4: Odds ratios and 95\% confidence intervals for the likelihood of severe arthralgia and persistent arthralgia $\geq 1$ year post-Chikungunya by demographic and clinical factors

\begin{tabular}{lcc}
\hline Variable & $\begin{array}{c}\text { Severe arthralgia } \\
\text { Odds ratio } \\
\mathbf{9 5 \%} \text { confidence level) }\end{array}$ & $\begin{array}{c}\text { Persistent arthralgia } \\
\text { Odds ratio } \\
\mathbf{9 5 \%} \text { confidence level) }\end{array}$ \\
\hline Gender: & 1 (reference) & 1 (reference) \\
Males & $2.44(1.08,5.52)$ & $2.18(1.09,4.39)$ \\
Females & 1 (reference) & - \\
Pre-existing arthritis & $3.78(1.23,11.62)$ & - \\
No & Yes &
\end{tabular}

Odds ratios were adjusted for gender, age groups, education, pre-existing arthritis, diabetes and hypertension, and duration of symptoms.

Persistent arthralgia occurred in $30.7 \%$ of the arthralgic participants, and somewhat fewer patients $(27.5 \%)$ reported severe arthralgia in the previous month. Females showed a greater likelihood for severe arthralgia as well as persistent arthralgia, and patients who reported severe arthralgia were more likely to have pre-existing arthritis.
Our findings are consistent with previous reports of arthralgia as a long-term sequela of CHIKV infection.

Persistent arthralgia associated with CHIKV infection has been described in Southeast Asia, South America, Europe $(10,19)$ and the US Virgin Islands (16) with prevalence that ranged widely (7-79\%). In this study, $30.7 \%$ of the arthralgic subjects reported persistent arthralgia which is consistent with prevalence estimates shown in the pooled estimates (40\%; 95\% CI: $31 \%, 49 \%$ ) by Rodriguez-Morales et al (10) and the US Virgin Islands in which 33\% of patients reported persistent arthralgia 12 months after the acute phase (15).

We evaluated demographic and clinical factors that were associated with persistent arthralgia as well as the severity of pain. The female gender was positively related to self-reported persistent arthralgia and has been documented elsewhere (20). One-half of the patients in this study who reported persistent arthralgia sought medical care and pointed to the incapacitating nature of the disease. However, it should be noted that $15.2 \%$ of patients with persistent arthralgia had arthritis prior to the onset of the infection. Hence, we may have overestimated the prevalence of persistent arthralgia due to progressive osteoarthritis associated with the ageing process.

Approximately one-quarter $(27.5 \%)$ of patients with arthralgia described the pain during the previous month to be severe. Chronic severe arthralgia is associated with deteriorated functional status (21). Females were more likely to report severe as well as persistent arthralgia, and it was suggested that gender differences in biological and psychosocial factors relating to pain sensitivity may explain the findings. Fillingim advanced that sex hormones (biological factors) were likely to mediate gender differences resulting in females being at greater risk of developing several chronic pain disorders (22).

The present study suggests that a pre-existing rheumatologic disease (arthritis) may play a role in severe arthralgia. A pre-existing joint disease has been shown to increase the susceptibility to CHIKV infection (23). A study by Sissoko et al revealed that underlying osteoarthritis, severity of arthralgia during the acute phase and being 45 years or older were independently associated with joint disease (9). However, they pointed out that collection of data on the presence or absence of a pre-existing joint disease by self-reports was likely to confound this relationship as orthropaedic evaluations were rarely performed at the time of or prior to acute infection. Thus, an association between a pre-existing 
joint disease and $\mathrm{CHIKV}$-associated persistent arthralgia cannot be confirmed (24).

A causal role for long-term chronic arthralgia associated with CHIKV infection is poorly understood. It was suggested that early infection of human monocytes by the virus was likely to contribute to chronic arthralgia as infected monocytes had been found in the synovial tissues of patients with persistent arthralgia (25). Others hypothesized that viral persistence and induction of autoimmune disease were possible mechanisms of chronic joint disease (26).

The Aedes aegypti mosquito is endemic in Jamaica and is the vector for transmission of CHIKV as well as dengue (27). In its classical form, CHIKV has similar clinical presentation as dengue, thereby increasing the likelihood of misdiagnosis in countries where the two viruses co-circulate (28). However, in contrast to dengue, CHIKV infection is characterized by a chronic phase of illness lasting weeks to years subsequent to the acute phase of the infection whereas thrombocytopenia is more frequently found in dengue (29).

\section{Strengths and limitations}

Our study's confirmation of earlier findings of the prevalence of persistent arthralgia and the contribution of gender to chronic CHIKV $(10,16)$ supports the reliability of our data. Furthermore, we enrolled equal proportions of both genders to overcome selection bias of higher female attendance at health clinics mainly due to reproductive-related factors and children's healthcare. We also collected information on arthritis as a pre-existing rheumatologic disorder and applied it as a covariate in logistic regression models to determine its independent contribution.

Notwithstanding, reports of arthralgia were selfperceptions without a physician's assessment of articular inflammatory signs and laboratory confirmation of CHIKV using blood samples for the detection of anti-CHIKV IgM and IgG antibodies (30). Our study also investigated patients in the public primary care setting and may not be representative of private primary care patients or more severe cases treated at secondary and tertiary health facilities.

\section{CONCLUSION}

This study highlights the occurrence of CHIKVassociated chronic arthralgia in adult Jamaicans and provides information on the demographic and clinical factors associated with persistent and severe arthralgia.
Longitudinal studies are required to determine the longterm sequelae of CHIKV infection.

\section{REFERENCES}

1. Pialoux G, Gauzere BA, Jaureguiberry S, Strobel M. Chikungunya, an epidemic arbovirosis. Lancet Infect Dis 2007; 7: 319-27.

2. Couturier E, Guillemin F, Mura M, Leon L, Virion JM, Letort MJ et al. Impaired quality of life after chikungunya virus infection: a 2-year follow-up study. Rheumatology (Oxford) 2012; 51: 1315-22.

3. Thiberville SD, Moyen N, Dupuis-Maguiraga L, Nougairede A, Gould EA, Roques P et al. Chikungunya fever: epidemiology, clinical syndrome, pathogenesis and therapy. Antiviral Res 2013; 99: 345-70.

4. Weaver SC. Arrival of chikungunya virus in the new world: prospects for spread and impact on public health. PLoS Negl Trop Dis 2014; 8: e2921.

5. Van Bortel W, Dorleans F, Rosine J, Blateau A, Rousset D, Matheus S et al. Chikungunya outbreak in the Caribbean region, December 2013 to March 2014, and the significance for Europe. Euro Surveill 2014; 19: 20759.

6. Ozden S, Huerre M, Riviere JP, Coffey LL, Afonso PV, Mouly V et al. Human muscle satellite cells as targets of chikungunya virus infection. PLoS One 2007; 2: e527.

7. Her Z, Malleret B, Chan M, Ong EK, Wong SC, Kwek DJ et al. Active infection of human blood monocytes by chikungunya virus triggers an innate immune response. J Immunol 2010; 184: 5903-13.

8. Lokireddy S, Vemula S, Vadde R. Connective tissue metabolism in chikungunya patients. Virol J 2008; 5: 31.

9. Sissoko D, Malvy D, Ezzedine K, Renault P, Moscetti F, Ledrans M et al. Post-epidemic chikungunya disease on Reunion Island: course of rheumatic manifestations and associated factors over a 15-month period. PLoS Negl Trop Dis 2009; 3: e389.

10. Rodriguez-Morales AJ, Cardona-Ospina JA, Fernanda Urbano-Garzon S, Sebastian Hurtado-Zapata J. Prevalence of post-chikungunya infection chronic inflammatory arthritis: a systematic review and metaanalysis. Arthritis Care Res (Hoboken) 2016; 68: 1849-58.

11. Pan American Health Organization, World Health Organization. Zika epidemiological report Jamaica. Washington, DC: PAHO, WHO; 2017. Available from: www.paho.org/hq/dmdocuments/2017/2017-phe-zikasituation-report-jam.pdf [accessed November 12, 2017].

12. Crosby L, Perreau C, Madeux B, Cossic J, Armand C, HerrmannStorke $\mathrm{C}$ et al. Severe manifestations of chikungunya virus in critically ill patients during the 2013-2014 Caribbean outbreak. Int J Infect Dis 2016; 48: 78-80.

13. Mattar S, Miranda J, Pinzon H, Tique V, Bolanos A, Aponte J et al. Outbreak of chikungunya virus in the north Caribbean area of Colombia: clinical presentation and phylogenetic analysis. J Infect Dev Ctries 2015; 9: 1126-32.

14. Teo TH, Her Z, Tan JJ, Lum FM, Lee WW, Chan YH et al. Caribbean and la reunion chikungunya virus isolates differ in their capacity to induce proinflammatory Th1 and NK cell responses and acute joint pathology. J Virol 2015; 89: 7955-69.

15. Feldstein LR, Ellis EM, Rowhani-Rahbar A, Halloran ME, Ellis BR. The first reported outbreak of chikungunya in the US Virgin Islands, 2014-2015. Am J Trop Med Hyg 2016; 95: 885-9.

16. Feldstein LR, Rowhani-Rahbar A, Staples JE, Weaver MR, Halloran ME, Ellis EM. Persistent arthralgia associated with chikungunya virus outbreak, US Virgin Islands, December 2014-February 2016. Emerg Infect Dis 2017; 23: 673-6.

17. Duncan J, Gordon-Johnson KA, Tulloch-Reid MK, Cunningham-Myrie C, Ernst K, McMorris N et al. Chikungunya: important lessons from the Jamaican experience. Rev Panam Salud Publica 2017; 41: e60.

18. The World Medical Association, Inc. Declaration of Helsinki - Ethical Principles for Medical Research Involving Human Subjects. 2008. Available at: www.wma.net/wp-content/uploads/2016/11/DoHOct2008.pdf. 
19. Rodriguez-Morales AJ, Gil-Restrepo AF, Ramirez-Jaramillo V, Montoya-Arias CP, Acevedo-Mendoza WF, Bedoya-Arias JE et al. Post-chikungunya chronic inflammatory rheumatism: results from a retrospective follow-up study of 283 adult and child cases in La Virginia, Risaralda, Colombia. F1000Research 2016; 5: 360.

20. Campbell CM, Edwards RR. Ethnic differences in pain and pain management. Pain Manag 2012; 2: 219-30.

21. Rahim AA, Thekkekara RJ, Bina T, Paul BJ. Disability with persistent pain following an epidemic of chikungunya in rural South India. J Rheumatol 2016; 43: 440-4.

22. Fillingim RB. Sex, gender, and pain: women and men really are different. Curr Rev Pain 2000; 4: 24-30.

23. Jaffar-Bandjee MC, Das T, Hoarau JJ, Krejbich TP, Denizot M, Ribera A et al. Chikungunya virus takes centre stage in virally induced arthritis: possible cellular and molecular mechanisms to pathogenesis. Microbes Infect 2009; 11: 1206-18.

24. Goupil BA, Mores CN. A review of chikungunya virus-induced arthralgia: clinical manifestations, therapeutics, and pathogenesis. Open Rheumatol J 2016; 10: 129-40.

25. Hoarau JJ, Jaffar Bandjee MC, Krejbich TP, Das T, Li-Pat-Yuen G, Dassa $\mathrm{B}$ et al. Persistent chronic inflammation and infection by chikungunya arthritogenic alphavirus in spite of a robust host immune response. J Immunol 2010; 184: 5914-27.

26. Hawman DW, Stoermer KA, Montgomery SA, Pal P, Oko L, Diamond MS et al. Chronic joint disease caused by persistent chikungunya virus infection is controlled by the adaptive immune response. J Virol 2013; 87: $13878-88$.

27. Nasci RS. Movement of chikungunya virus into the Western hemisphere. Emerg Infect Dis 2014; 20: 1394-5.

28. Dupuis-Maguiraga L, Noret M, Brun S, Le GR, Gras G, Roques P. Chikungunya disease: infection-associated markers from the acute to the chronic phase of arbovirus-induced arthralgia. PLoS Negl Trop Dis 2012; 6: e1446.

29. Mohd Zim MA, Sam IC, Omar SF, Chan YF, AbuBakar S, Kamarulzaman A. Chikungunya infection in Malaysia: comparison with dengue infection in adults and predictors of persistent arthralgia. J Clin Virol 2013; 56: $141-5$.

30. Malvy D, Ezzedine K, Mamani-Matsuda M, Autran B, Tolou H, Receveur MC et al. Destructive arthritis in a patient with chikungunya virus infection with persistent specific IgM antibodies. BMC Infect Dis 2009; 9: 200. 